\title{
Effects of White Turmeric Infusion on the Liver Cells in Carbon Tetrachloride-Induced Mice
}

\author{
Fitria Oktaviani, ${ }^{1}$ R. B. Soeherman Herdiningrat, ${ }^{2}$ Herry Yulianti ${ }^{3}$ \\ ${ }^{1}$ Faculty of Medicine Universitas Padjadjaran, ${ }^{2}$ Department of Anatoy and Cell Biology Faculty \\ of Medicine Universitas Padjadjaran, ${ }^{3}$ Department of Anatomical Pathology Faculty of Medicine, \\ Universitas Padjadjaran/Dr. Hasan Sadikin General Hospital Bandung
}

\section{Abstract}

Background: The liver is an organ that has important functions in the body. Liver damage can be caused by oxidative stress and free radicals. White turmeric (Curcuma zedoaria L) contains antioxidants that can be used to neutralize the effects of free radicals. This study was conducted to determine the effect of white turmeric infusion on histological appearance of liver cells in male mice induced by carbon tetrachloride (CCl4).

Methods: This laboratory experimental study was conducted using male mice (Mus musculus) with Balb/c strain. Thirty-three mice were randomly divided into 3 groups i.e.,group 1 as a control group was given standard food and drink, group 2 was given $10 \%$ of CCl4 $0.1 \mathrm{ml}$ by intraperitoneal injection on the first day and group 3 was given $10 \%$ of CCl $40.1 \mathrm{~mL}$ by intraperitoneal injection on the first day, followed by the administration of $50 \%$ of white turmeric infusion $0.2 \mathrm{~mL}$. Kruskal-Wallis test method was used to analyse the significant differences of the average percentage of damaged liver cells in the group given CCl4 alone with the group given $\mathrm{CCl} 4$ and white turmeric infusion and control group.

Results: The percentage of damaged liver cells between groups of mice given $\mathrm{CCl} 4$ alone and the group given $\mathrm{CCl} 4$ followed by white turmeric infusion were respectively $(\mathrm{p}<0.05)$ compared to group 1 .

Conclusions: Administration of white turmeric infusion gave an influence by decreasing the percentage of damaged liver cells in CCl4-induced mice. White turmeric can serve as an alternative antioxidants that can be used to neutralize the effects of free radicals. [AM].2015;2(4):506-10]

Keywords: Carbon tetrachloride, liver cells, white turmeric

\section{Introduction}

Liver as an organ that bears important functions in the body is very susceptible to damage from metabolic disorders, circulation, toxic substances, microbes, and malignancy. ${ }^{1}$ One of the most serious liver diseases is hepatocellular carcinoma, with risk factors such as hepatitis B or C infections and longterm alcohol consumption. ${ }^{1}$ As many as $82 \%$ cases of hepatocellular carcinoma are found in an endemic area of hepatitis B and C, especially in Asia and Africa. ${ }^{2}$

Hepatitis virus can cause liver tissue damage and inflammation through the formation of free radicals which induce mutation and transformation of normal hepatocyte cells into malignant cells. ${ }^{3}$ Other agents that can cause liver damage are chemical agents. Chemical agents often cause subclinical injury to the liver, which manifest only as abnormal liver enzyme tests.

Carbon tetrachloride (CCl4) is a chemical widely used as cleaning agents, solvents, as well as industrial materials. ${ }^{4}$ The CCl4 entering the body will be metabolized in the liver to form trichloromethyl radicals and further initiate lipid peroxidation process in liver cells to cause tissue damage. ${ }^{5}$

White turmeric (Curcuma zedoaria L) is a plant of the genus Curcuma contains various antioxidants such as phenolic and flavonoides, and terpenoides. ${ }^{6}$ Such compounds can be used as an analgesic, anti-inflammatory, and may provide protection to the liver cells from damage caused by chemical agents. ${ }^{7}$ This study aimed to determine the effect of white turmeric infusion on the histological appearance of the liver cells CCl4-induced mice.

Correspondence: Fitria Oktaviani, Faculty of Medicine, Universitas Padjadjaran, Jalan Raya Bandung-Sumedang Km.21, Jatinangor, Sumedang, Indonesia, Phone: +62812201106627 Email: fitria.oktaviani@gmail.com 


\section{Methods}

This experimental study was conducted in the laboratory of the Department of Cell Biology, Faculty of Medicine Universitas Padjadjaran from August to November 2012. The total of mice used as sample was determined by using the Federer formula $(r-1)(t-1) \geq 15$, where $r$ is the total of samples and $t$ is the total of treatment groups. Based on these calculations, we determined that the value of $\mathrm{r}$ or number of samples was $\geq 8.5$. In this study, the total of samples used in each group was 11 mice to anticipate an event of exclusion during adaptation. Inclusion criteria in this study, the mice had an average weight of 20-25 grams and age of 2 months old.

Mice in accordance with the inclusion and exclusion criteria were adapted for 7 days. During the adaptation period and throughout the experimental period, the mice were fed a standard pellets and water. After the adaptation period, the mice were put into 3 groups randomly. Group 1 served as control group. Mice from group 2 were given $\mathrm{CCl} 4$ injection on the first day only and then were observed for 7 days. Mice from group 3 was given $\mathrm{CCl} 4$ injection on the first day and then followed by administration of white turmeric infusion 2 hours later. White turmeric infusion was given once daily until the $7^{\text {th }}$ day of experiment.

The $\mathrm{CCl} 4$ of $10 \%$ concentration was achieved by dissolving $0.3 \mathrm{~mL}$ of pure $\mathrm{CCl} 4$ with $0.7 \%$ of liquid paraffin. As much as 0.1 $\mathrm{mL}$ of $\mathrm{CCl} 4$ was injected intraperitoneally to induce liver tissue damage.

For making the infusion, white turmeric rhizomes were peeled and cut into small pieces, weighed up to 50 grams and then mixed with $100 \mathrm{~mL}$ of water in a pot. A pan filled with water was heated until it reached a temperature of $90^{\circ} \mathrm{C}$, and then placed the pot containing the mixture of white turmeric and water on it. Heated for 15 minutes and stirred. Then the mixture was filtered and poured into a tube. White turmeric infusion was given to the mice using a feeding tube as much as 0.2 mL per day, each day.

By the end of the experiment, the mice were anesthetized using chloroform and then fixed on a surgical table. As much as $5 \mathrm{~mL}$ saline and formaldehyde solution were prepared in syringes. Laparotomy began with an incision on the lower abdomen up to the lower neck. A wing needle was attached in the left ventricle and connected with the syringe. A cut the inferior vena cava was made to drain the blood while saline solution was injected, followed by liquid formalin, then the ligaments of the liver were cut and the middle third portion of the largest lobe was taken as the sample.

The tissue was fixed using $37 \%$ of formaldehyde solution then rinsed and dehydrated with $100 \%$ of alcohol solution. Then we used xylol and toluol to cleanse the specimen before infiltrating the paraffin. After the paraffin hardened, the specimen was cut using microtome. Before staining procedure, specimens were cleaned with xylol and toluol followed by rehydration using alcohol solution. The staining procedure was done by using a solution of hematoxylin and eosin counterstain.

Microscopic observation was conducted to see the effect of treatment on the liver cells qualitatively and quantitatively. Qualitative assessment was done microscopically with 400x magnification, while quantitative observation was done by counting the average percentage of injured cells.

The data were then analysed using the non-parametric Kruskal-Wallis test on SPSS. It aimed to prove the significant differences of the average percentage of damaged liver cells in the group given $\mathrm{CCl} 4$ alone with the group given $\mathrm{CCl} 4$ and white turmeric infusion and control group as negative control was given standard food and drink.

\section{Results}

The percentage of damaged liver cells from each group was presented (Table 1). Alteration of the liver tissue architecture in the group administrated with injection of CCl4 was shown by the presence of lightcolored cytoplasmic vacuoles and fusion of cell membranes.

Necrotic materials and lymphocyte cells were found mainly near the central vein (Figure $1)$. In the group of mice treated with white turmeric infusion two hours following $\mathrm{CCl} 4$ injection, necrotic materials were abundant in surrounding central vein but not as many

Table 1 Percentage of Damaged Liver Cells in Mice

\begin{tabular}{lc}
\hline \multicolumn{1}{c}{ Group } & Average \\
\hline Control & $6.80 \%$ \\
CCl4 & $90.75 \%$ \\
CCl4 + White turmeric & $37.7 \%$ \\
\hline
\end{tabular}




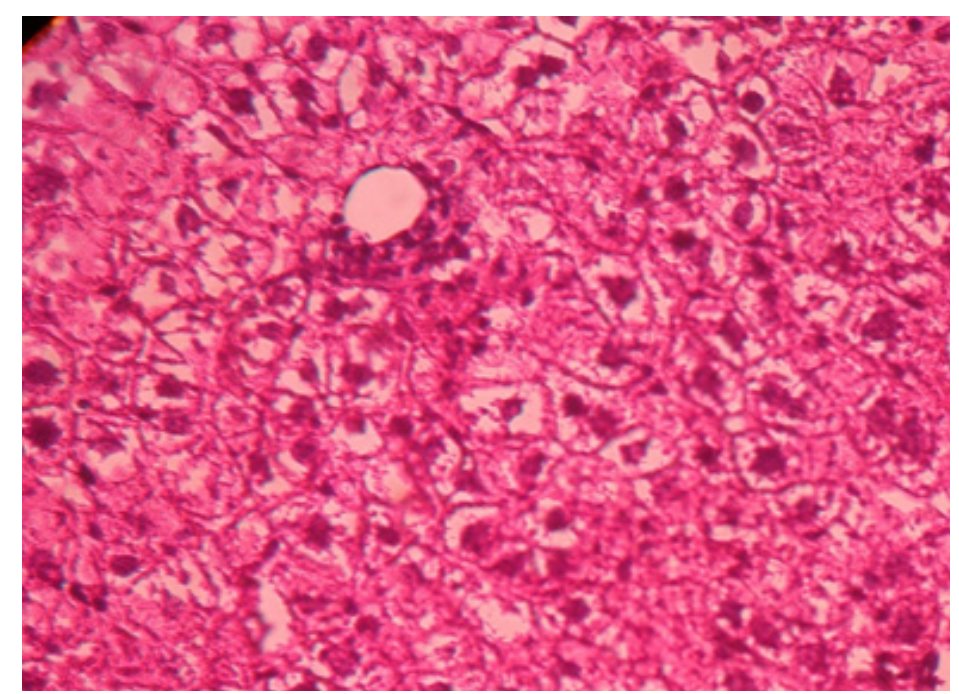

Figure 1 Liver Cells of CCl4-induced Mice

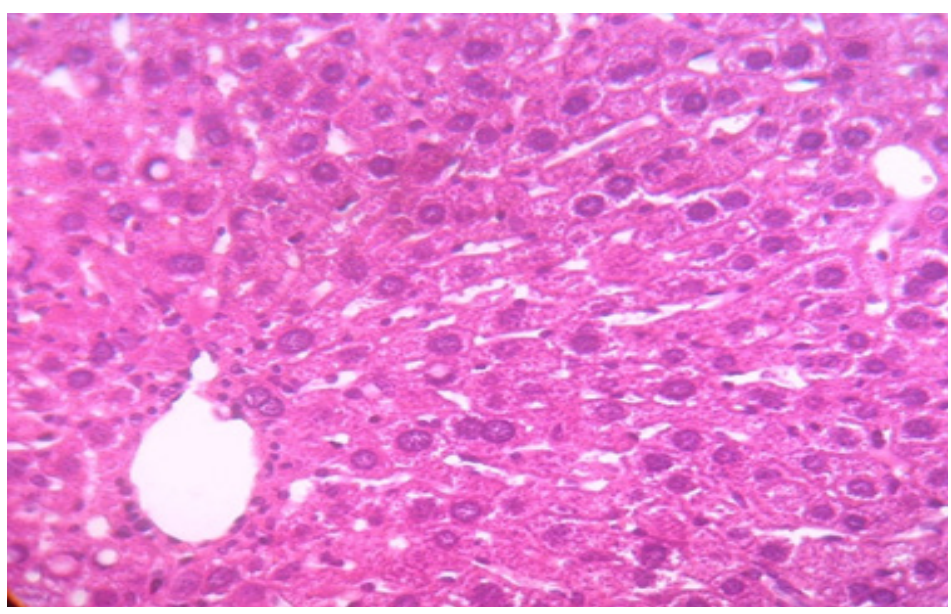

Figure 2 Liver Cells of The Group Treated With White Turmeric Infusion Following CCI4 Induction

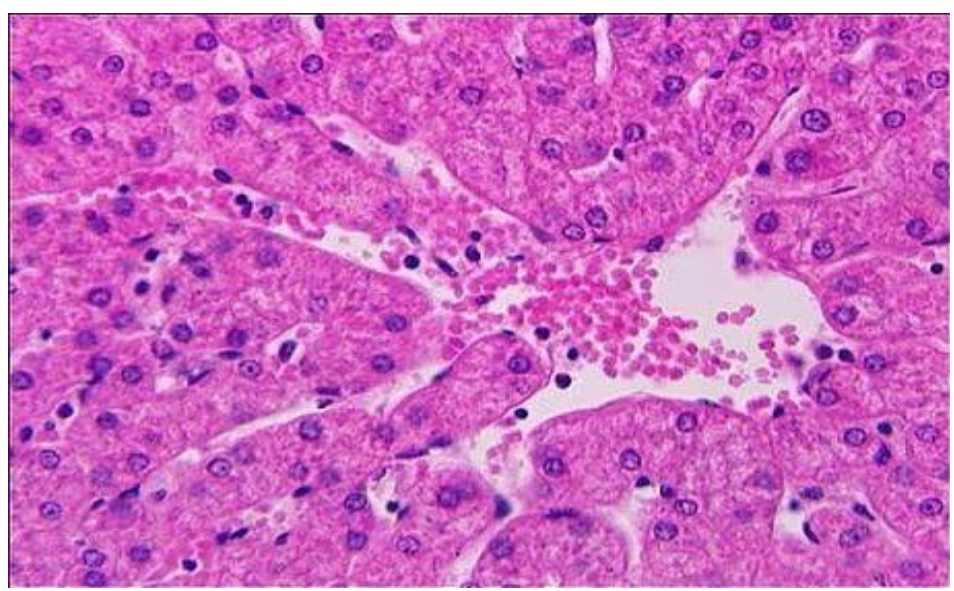

Figure 3 Liver Cells of The Group Control 
as in the group given $\mathrm{CCl} 4$ alone. There were some evidences of mitotic activity. Sinusoids were deranged but identifiable (Figure 2). Administration of white turmeric infusion significantly decreased the percentage of damaged cells in mice previously induced with CCl4 ( $\mathrm{p}<0.05), 37.7 \%$ from groups sample.

\section{Discussions}

Liver damage caused by hepatotoxic substances generally occurs in liver cells of the group treated with white turmeric infusion following $\mathrm{CCl} 4$ induction, reflecting the enzymes that play a role in the metabolism of such substances. ${ }^{8}$ CCl4 metabolism produced an accumulation of free radicals that can damage the cell membrane or DNA directly. ${ }^{9}$ Prolonged liver damage or cirrhosis is associated with the occurrence of hepatocellular carcinoma. Risk factors for hepatocellular carcinoma itself include chronic liver infection, metabolic liver disease, and liver cirrhosis of any cause. ${ }^{3}$ In Indonesia, $44-45 \%$ of patients with liver cirrhosis and hepatocellular carcinoma were positive for hepatitis B detection. ${ }^{10}$ Hepatocellular carcinoma can also occur in conditions where the liver histological structure was altered. ${ }^{3}$ In mice and rats, administration of $\mathrm{CCl} 4$ may cause hepatocellular carcinoma. ${ }^{5} \mathrm{CCl} 4$ is shown to have genotoxic and mutagenic effects associated with the cytotoxicity, lipid peroxidation, and oxidative stress. ${ }^{5}$ The effect of long-term exposure to CCl4in humans has not been widely reported, but acute exposure of CCl4 is associated with the onset of various signs and symptoms such as liver enlargement (hepatomegaly), increased aspartate aminotransferase and alanine transferase enzymes, and elevated levels of bilirubin. ${ }^{5}$

Rhizome white turmeric (Curcuma zedoaria L) has a variety of antioxidants that can be used as an analgesic and antiinflammatory. It also prevent the development of cancer cells and protect liver cells from the harmful effects of toxic chemicals. ${ }^{7}$ The effect of acetone extract and other ingredients isolated from white turmeric rhizome such as furanodiene, curdione, neocurdione, 13-hydroxygermacrone, zederone, and curcuminoid with a dose of $12.5-50 \mathrm{mg} / \mathrm{kg}$ through oral administration has revealed to protect liver cells from damage caused by D-GalN/LPS induction in mice, assessed by the levels ofaspartate aminotransferase (AST) and alanine transferase (ALT) enzymes in serum. ${ }^{11}$ Administration of curcumin to the Sprague-
Dawley strain rats at a dose of $200 \mathrm{mg} / \mathrm{kg}$ and $400 \mathrm{mg} / \mathrm{kg}$ has shown to provide protective and therapeutic effects on liver cells exposed to $\mathrm{CCl} 4$ by inhibiting the inflammatory process and oxidative stress. ${ }^{12}$ Curcumin alters the transcription processes in the regulation of gene expressions that regulate the cell and inhibits the process of inflammation, tumor formation, angiogenesis, cell division and cellular invasion. ${ }^{13}$ Administration of curcumin can inhibit inflammatory processes and fibrogenesis by suppressing the production of various cytokines such as TNF- $\alpha$, IFN- $\gamma$, IL-6. It also restrains the process of collagen deposition. ${ }^{12}$ Curcumin is well tolerated in the body, thereby reducing the probability of toxicity.13 Other antioxidant substances in white turmeric also play a role in inhibiting the cytotoxicity and the production of nitric oxide (NO) produced in the process of inflammation. ${ }^{11}$

In this study, induction of $\mathrm{CCl} 4$ caused damage liver cells in mice shown by the widespread histological changes. While in the group of mice given white turmeric infusion following $\mathrm{CCl} 4$ induction, the average percentage of damaged liver cells were significantly lower. This is consistent with the previous studies proving that the antioxidant contents of white turmeric rhizome can be used in the prevention and treatment of damage to the liver cells. ${ }^{11}$ Several studies have reported that the major histopathological parameters altered with CCl4-induced damage are degeneration in hepatocytes, the presence of necrosis and inflammatory infiltration. Our histology analyses showed a positive effect of white turmeric in inhibiting the in the process of inflammation. ${ }^{12}$

This laboratory experimental study has several limitations, including a small size sample. In this study, induction of $\mathrm{CCl} 4$ caused damage liver cells in mice shown by the widespread histological changes. Carbon tetrachloride $(\mathrm{CCl} 4)$ is a chemical widely used as cleaning agents, solvents, as well as industrial materials Future study with large size sample seems warranted to resolve these and other related issues.

\section{References}

1. Kumar V, Abbas AK, Fausto N, Aster JC. Robbins and cotran pathologic basis of disease. 8th ed. Philadelphia: Saunders Elsevier; 2010.

2. El-Serag HB. Hepatocellular Carcinoma. N Engl J Med. 2011;365(12):1118-27. 
3. Fattovich G, Stroffolini T, Zagni I, Donato F. Hepatocellular carcinoma in cirrhosis: incidence and risk factors. Gastroenterology. 2004;127(5 Suppl 1): S35-50.

4. United States Department of Health and Human Services. Toxicological profile for carbon tetrachloride. Atlanta: United States Department of Health and Human Services; 2005 [cited 2012 September 20]; Available from: http://www.atsdr.cdc. gov/toxprofiles/tp30.pdf.

5. United States Environmental Protection Agency. Toxicological review of carbon tetrachloride. Washington, DC: United States Environmental Protection Agency; 2010 [cited 2012 September 17]; Available from: http://www.epa.gov/iris/ toxreviews/0020tr.pdf.

6. Cho WY, Kim SJ. Anti-oxidative actions of Curcuma zedoaria extract with inhibition of inducible nitric oxide synthase (iNOS) induction and lipid peroxidation. J Med Plants Res. 2012;6(22):3837-44.

7. Lobo R, Prabhu KS, Shirwaikar A. Curcuma zedoaria rosc. (white turmeric): a review of its chemical, pharmacological and ethnomedicinal properties. J Pharm Pharmacol. 2009;61(1):13-21.

8. Ramachandran R, Kakar S. Histological patterns in drug-induced liver disease. J Clin Pathol. 2009;62(6):481-92.

9. Panjaitan RGP, Handharyani E, Chairul, Masriani, Zakiah Z, Manalu W. Pengaruh pemberian karbon tetraklorida terhadap fungsi hati dan ginjal tikus. Makara Kesehatan. 2007;11(1):11-6.

10. Merican I, Guan R, Amarapuka D, Alexander M, Chutaputti A, Chien R, et al. Chronic hepatitis B virus infection in Asian countries. J Gastroenterol Hepatol. 2000; 15(12):1356-61.

11. Morikawa T, Matsuda $H$, Ninomiya $K$, Yoshikawa M. Potent protective effects of sesquiterpenes and curcumin from zedoariae rhizoma on liver injury induced by d-galactosamine/lipopolysaccharidase or tumor necrosis factor alpha. Biol Pharm Bull. 2002;25(5):627-31.

12. Fu Y, Zheng S, Lin J, Ryerse J, Chen A. Curcumin protects the rat liver from CCl4-caused injury and fibrogenesis by attenuating oxidative stress and suppressing inflammation. Mol Pharmacol. 2008;73(2):399-409.

13. Rivera-Espinoza Y, Muriel P. Pharmacological actions of curcumin in liver disease or damage. Liver Int. 2009; 29(10):1457-66. 